\title{
TOTAL FLAVONOID CONTENT OF FALOAK (STERCULIA QUADRIFIDA) BARK IN VARIETIES OF BARK COLOUR, TREE DIAMETER AND GROWTH ALTITUDE
}

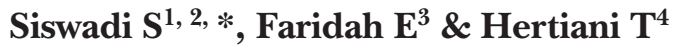 \\ ${ }^{1}$ Banjarbaru Environment and Forestry Research and Development Institute, Banjarbaru 70721, Indonesia \\ ${ }^{2}$ Kupang Environment and Forestry Research and Development Institute, Kupang 85119, Indonesia \\ ${ }^{3}$ Department of Silviculture, Faculty of Forestry, Gadjah Mada Unversity, Yogyakarta 55281, Indonesia \\ ${ }^{4}$ Department of Pharmaceutical Biology, Faculty of Pharmacy, Gadjah Mada Unversity, Yogyakarta 55281, Indonesia \\ *zieslitbanglhk@gmail.com
}

Received June 2021; accepted October 2020

\begin{abstract}
Sterculia quadrifida (Sterculiaceae) grows in Indonesia, India, Timor Leste and Australia. In East Nusa Tenggara province, Indonesia, particularly in Timor Island, S. quadrifida is called 'faloak' and its bark is used to treat hepatitis. This study aims to determine the correlation between total flavonoid content and varieties of bark colour, tree diameter class and altitudes, and to examine the interaction between tree diameter class and altitudes in terms of flavonoid content. Sterculia quadrifida barks were collected from four altitude strata of $\leq 300,>300-600,>600-900$ and $>900 \mathrm{~m}$ a.s.l. Each stratum of altitude consisted of three diameter classes of $\leq 15,>15-30$ and $>30 \mathrm{~cm}$. Bark colour was classified using Munsell colour chart. The powdered barks were macerated with $96 \%$ ethanol and evaporated to yield thick extracts. The total flavonoid content of each extract was measured by spectrophotometry. There were four dominant colour groups, i.e., red, brown, yellow and orange. The highest total flavonoid content was found in the red $(0.25 \%)$ and yellow $(0.25 \%)$ barks. The results showed that the highest total flavonoid content was found in tree diameter of $>$ $15-30 \mathrm{~cm}$, with a total flavonoid of $0.22 \%$. The highest total flavonoid content $(0.21 \%)$ was observed in the barks from altitude range of $\leq 300 \mathrm{~m}$ a.s.l. There was a weak interaction between altitude and tree diameter on the extract yield and total flavonoid of S. quadrifida bark.
\end{abstract}

Keywords: Hepatitis, karst, semi-arid, Sterculiaceae, Timor island

\section{INTRODUCTION}

The use of plants as herbal ingredients has not been fully explored. The large number of plants, yet to be analysed for their bioactive compounds, may be useful to improve human health (RoshanJahn et al. 2018). Sterculia quadrifida belongs to the Sterculiaceae family and is naturally distributed to Indonesia, India, Timor Leste and Australia (Mau 2010, Karthikeyan et al. 2014, Akter 2016). In West Timor, this plant is known as faloak. In East Nusa Tenggara Province, Indonesia, the plant spreads through Timor, Sumba, Flores, Alor and Rote (Siswadi et al. 2020). Sterculia quadrifida is also commonly found in Timor Island, especially in Timor Tengah Selatan District and Kupang District (Siswadi et al. 2013).

Sterculia quadrifida is used to treat hepatitis by boiling the bark, and the decoction is consumed several times a day. The number of hepatitis cases in East Nusa Tenggara Province is highly significant, thus, S. quadrifida is widely used for community treatment. Its bark contains flavonoids, phenolics, alkaloids and terpenoids with potent antioxidant activity (Siswadi et al. 2014, Lulan et al. 2018, Saragih \& Siswadi 2019). Sterculia quadrifida bark extract can also be a potential immunomodulator and is used as an ingredient in breast cancer medicine (Rollando \& Prilianti 2017, Hertiani et al. 2019, Winanta et al. 2019).

The content of flavonoids in stem bark is usually higher than that of other plant parts such as leaves and branches (Wang et al. 2005). Flavonoids are a group of secondary metabolites synthesised by plants, consisting of anthocyanins, chalcones, flavanones, flavones, flavonols and isoflavones. Plant flavonoids have an essential role in protecting them from insects and pathogens, as well as UV light (Harborne 1988). Other than that, flavonoids also promote growth and stimulate pollen formation (Vicente 
\& Boscaiu 2018). In some studies, flavonoids have shown anti-inflammatory and anti-carcinogenic activities, and can improve vascular health and reduce hypertension risk. Medicinal plant antibacterial properties are contributed by their flavonoid content (Manik et al. 2014).

Flavonoid content is generally correlated with antioxidant activity. Phytochemical content in plants is influenced by sunlight, climate and soil. In addition, the harvested plant part, harvest time/season, and harvesting techniques can influence the phytochemical content (Mhamdi et al. 2010, Peschel et al. 2013). The diameter of a medicinal plant bark is thought to correlate with its phytochemical content. A study on tannin content in medicinal plant barks found that tannin percentage increased with tree diameter (Pandey \& Mandal 2012). In addition to environmental factors and tree diameter, the plant colour also correlates with its active compound content. For example, the yellow colour is produced by flavonoids (Zvavamwe et al. 2016).

However, the community does not have specific criteria in choosing $S$. quadrifida trees for debarking, and prefers to take barks that have never been peeled and closer to the access roads (Figure 1). Information on the influence of bark colour, tree diameter and elevation that produce optimum flavonoids can be recommended in selecting $S$. quadrifida bark to be harvested. This was the first study investigating the total flavonoid content in S. quadrifida bark from different bark colours, diameter classes and altitudes. The research aimed to identify whether bark colour, stem diameter and growth altitude of S. quadrifida tree correlated with their extraction yield and flavonoid content.

\section{MATERIALS AND METHODS}

Sterculia quadrifida bark sample collection was carried out in Kupang City, Kupang District, Timor Tengah Selatan District and Timor Tengah Utara District in 2014 and 2015 (Figure 2). Dried bark processing and quantitative analysis were carried out at the Laboratory of Pharmaceutical Biology, Faculty of Pharmacy, Gadjah Mada University, Yogyakarta. Physical and chemical soil parameter analysis were conducted at Balai Pengkajian Teknologi Pertanian (BPTP), Yogyakarta.

Faloak herbarium sample was identified as 373/IPH.1.02/If.8/III at the Research Center for Biology, Indonesian Institute of Sciences. For uniformity, bark samples were taken from the stem that is facing east, as high as $\pm 1 \mathrm{~m}$ above ground. The peeled bark was non-stripped and not the regrown. Regrown bark is lighter in colour with a more prominent surface than the non-stripped bark.

The diameter class was used as an approach to estimate the age of $S$. quadrifida trees. Cultivated S. quadrifida tree stands could not be used for the estimation of tree age. Sampling locations were divided into four, according to altitude

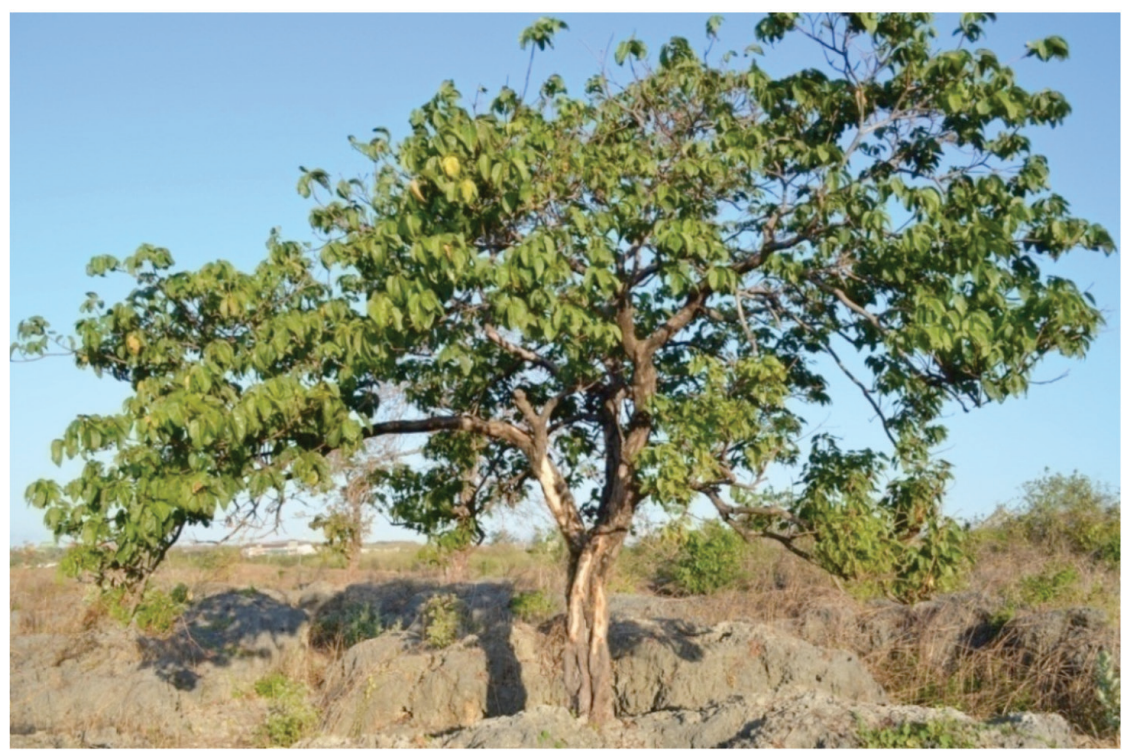

Figure 1 Sterculia quadrifida tree growing on karst with stripped off stem bark 

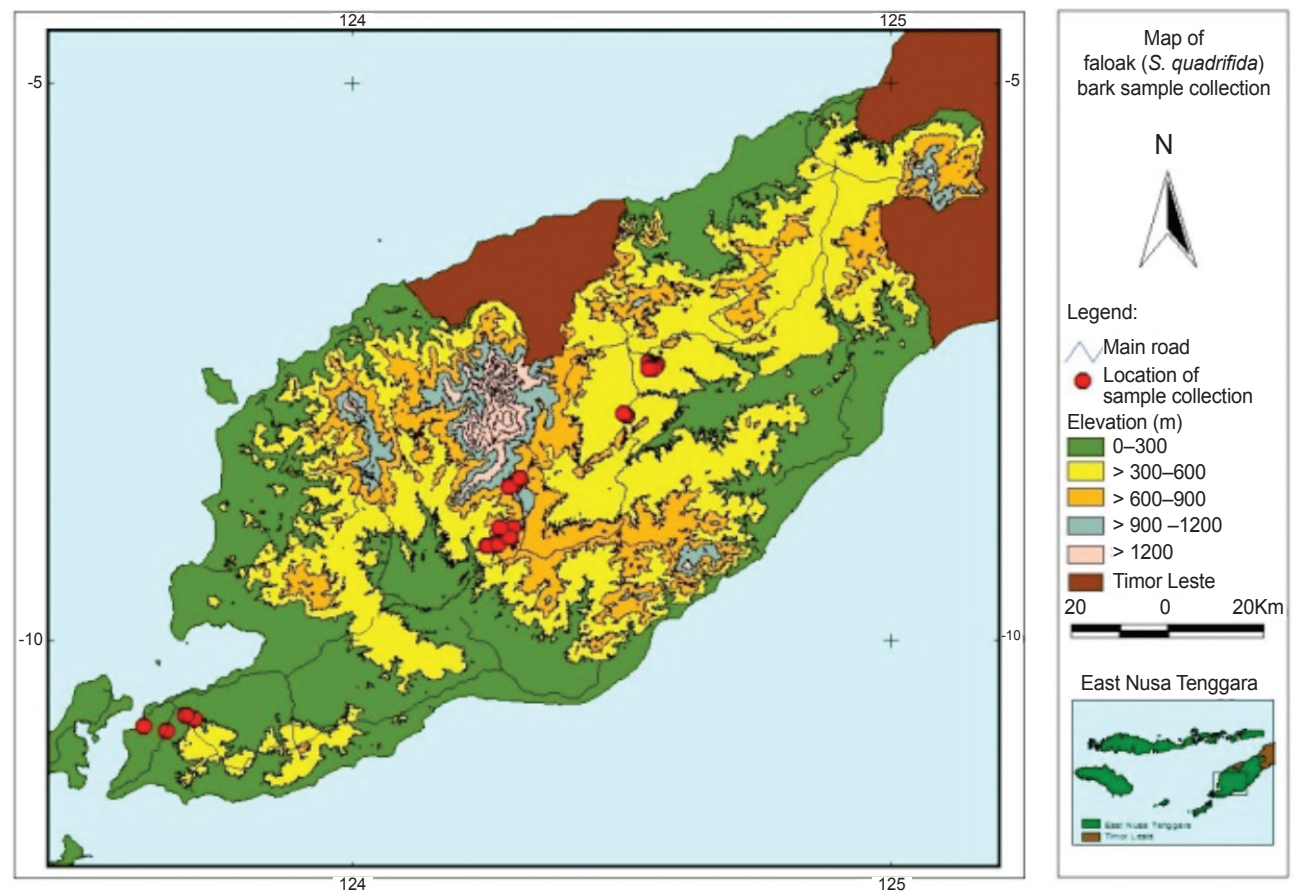

Figure 2 Location map of S. quadrifida bark sampling in Timor Island

categories of $\leq 300 \mathrm{~m}$ a.s.l, > 300-600 $\mathrm{m}$ a.s.l, > 600-900 $\mathrm{m}$ a.s.l and $>900 \mathrm{~m}$ a.s.l. In each altitude category, samples from 3 diameter classes were taken, namely diameter of $\leq 15 \mathrm{~cm},>15-30 \mathrm{~cm}$ and $>30 \mathrm{~cm}$. Thus, there were 12 sample group combinations in total, with three replications in each group, and 3-5 samples for each replication. The number of trees used for bark sampling was according to the availability in the field. From each tree sample, the bark used for the analysis was $\pm 250 \mathrm{~g}$.

\section{Bark sorting}

Bark sorting was carried out using two procedures, one for colour classification and one for total flavonoid content analysis. For colour classification, the barks were classified based on skin colour, regardless of diameter and height of the trees. Meanwhile, the barks obtained were sorted and grouped according to growth altitude and diameter class, for total flavonoid content analysis.

\section{Bark colour classification}

The collected bark samples were air-dried for seven days and chopped into $0.5-1 \mathrm{~cm}$ sizes. The chopped bark samples (20 g/tree) were subjected to colour classification using Munsell colour chart (Munsell Color Company 1994).
Barks with similar colours were collected in the same group (Figure 3).

\section{Extraction}

The chopped bark was grounded with a grinder and sieved using a 40-mesh sieve. The extraction method used was modified from Kementrian Kesehatan Republik Indonesia (2011). The maceration method used $96 \%$ ethanol solvent. Fifty gram of faloak powder was soaked in $300 \mathrm{~mL}$ 96\% ethanol for 48 hours and stirred 4-6 times in 24 hours. The next step was to vacuum the soaked powder to separate the macerate from the residue. The solution was then evaporated using a porcelain cup until a dry extract was obtained. The re-maceration process was terminated when the amount of extract obtained was between $0.01-0.02 \mathrm{~g}$.

\section{Determination of total flavonoid content}

Flavonoid content analysis was carried out twice: flavonoid content per colour group and flavonoid content per sample tree. Calculation of total flavonoid content was determined by UV-Vis spectrophotometry by using quercetin as a comparison and aluminum chloride $\left(\mathrm{AlCl}_{3}\right)$ as a reagent (Chang et al. 2002, Kementrian Kesehatan Republik Indonesia 2011). The total 


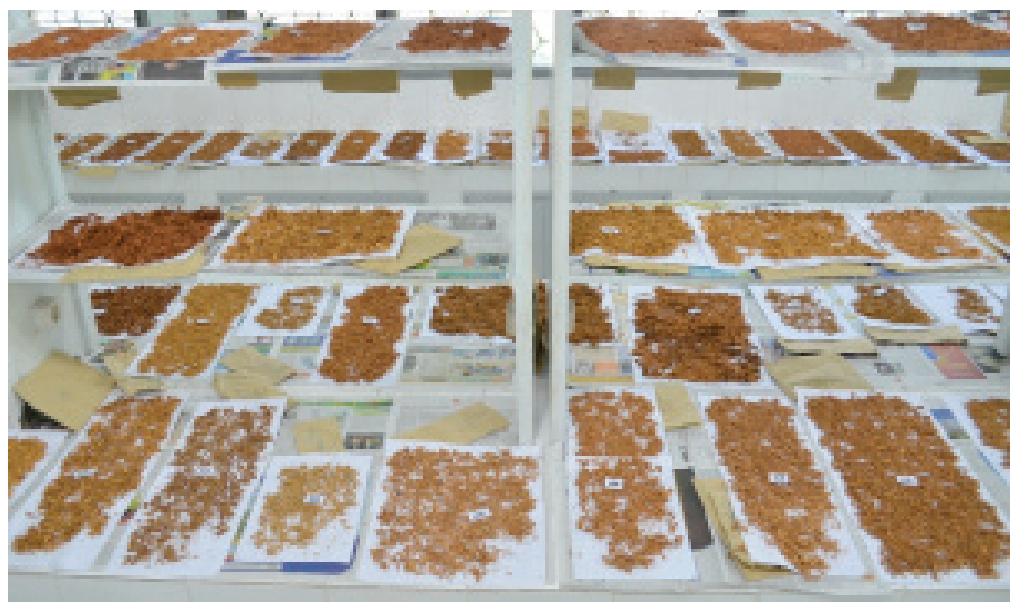

Figure 3 Sterculia quadrifida bark from each sample tree is dried prior to grouping by colour

flavonoid content was calculated as equivalent to $\mathrm{mg} / 100 \mathrm{~mL}$ quercetin (\%).

Quercetin standard curve was preceded by maximum quercetin wave reading, with a lambda max of $426 \mathrm{~nm}$. The standard curve was generated by a stock solution of $1 \mathrm{mg}$ / $\mathrm{mL}$ concentration, and a series of quercetin solutions $(25,50,75,100,125$ and $150 \mu \mathrm{g} / \mathrm{mL})$. A total of $0.5 \mathrm{~mL}$ of each concentration was mixed with $1.5 \mathrm{~mL}$ ethanol for analysis, $0.1 \mathrm{~mL}$ $\mathrm{AlCl}_{3}, 0.1 \mathrm{~mL} \mathrm{Na}$ acetate $1 \mathrm{M}$ and $2.8 \mathrm{~mL}$ distilled water. The blank consisted of $0.5 \mathrm{~mL}$ of each solution, mixed with $1.5 \mathrm{~mL}$ ethanol, $0.1 \mathrm{~mL} \mathrm{Na}$ acetate $1 \mathrm{M}$ and $2.9 \mathrm{~mL}$ distilled water. The test solution was incubated at room temperature for 30 minutes, and the absorption was measured with a UV-Vis spectrophotometer at a maximum wavelength of $426 \mathrm{~nm}$.

\section{Preparation of test solution}

A total of $0.2 \mathrm{~g}$ of bark extract was added to $2 \mathrm{~mL}$ of $80 \%$ ethanol to obtain a $100 \mathrm{mg} / \mathrm{mL}$ sample solution. A total of $0.5 \mathrm{~mL}$ of sample solution was mixed with $1.5 \mathrm{~mL}$ of $96 \%$ ethanol for analysis, $0.1 \mathrm{~mL}$ of $\mathrm{AlCl}_{3}, 0.1 \mathrm{~mL}$ of $1 \mathrm{M} \mathrm{Na}$ acetate and $2.8 \mathrm{~mL}$ of distilled water. The test solution was mixed using a vortex for 5 minutes, and allowed to stand for 10 minutes. Then, the sample was centrifuged for 5 minutes and measured by absorption using a UV-Vis spectrophotometer at a maximum wavelength of $426 \mathrm{~nm}$. The blank was similar to the test solution, but without the addition of $\mathrm{AlCl}_{3}$, which was replaced with distilled water, according to Kementrian Kesehatan Republik Indonesia (2011).

\section{Soil and climate parameters}

The collection of undisturbed and disturbed soil samples was carried out using a standard procedure (Balai Penelitian Tanah 2004). The soil samples were collected at a depth of $0-30 \mathrm{~cm}$ in four locations around each sampled tree. Samples from the same elevation were mixed thoroughly to provide a single composite. Soil texture was determined using a hydrometer and soil $\mathrm{pH}$ was measured with a $\mathrm{pH}$ meter. The procedure for the analysis of cation exchange capacity (CEC) is percolation. Organic C content was determined by the Walkley-Black method (Balai Penelitian Tanah 2009). Pusat Sains dan Teknologi Atmosfer LAPAN (National Institute of Aeronautics and Space) provided the rainfall data from 2010 to 2014 in each location. Since the climatology station was located far away from the sampling sites, the temperature and relative humidity were measured on-site using a thermohygrometer. Measurement of light intensity was carried out using a lux meter.

\section{Statistical analysis}

Data were reported as mean \pm standard deviation. ANOVA analysis was performed to determine whether there were differences in the total flavonoid content in the bark based on colour, growth altitudes and diameter class. The correlation was obtained by Pearson's correlation analysis. Statistical significance was set at 0.05. Statistical analyses were conducted using SPSS software (version 22). 


\section{RESULTS AND DISCUSSION}

\section{Bark colour}

For S. quadrifida bark colour, there were 17 group notations according to Munsell colour chart, which were further grouped into four major colour groups, namely red, brown, yellow and orange (Figure 3 ). The highest flavonoid levels were found in the red and yellow group, while the lowest in the orange group (Table 1).

The data showed that there was no correlation between flavonoid content and S. quadrifida bark colour. The total flavonoid content between different coloured stem did not differ significantly $(p>0.87)$. Therefore, the bark colour cannot be used as an indicator to predict the flavonoid content levels in $S$. quadrifida bark. The active compound that produces red and yellow colour is anthraquinone and flavonoids (Gupta 2019, Deveoğlu \& Karadağ 2019). The presence of tannin is a source of brown colour, thus, trees with brown, red or yellow wood produce a lot of tannins (Malviya \& Mahajan 2013). The colour of $S$. quadrifida bark may correlate with these compounds.

Visually, a S. quadrifida tree with a larger diameter, generally, has a darker red coloured bark than a smaller diameter. However, faloak trees with a diameter of less than $15 \mathrm{~cm}$ were also found to have red bark. Trees with small diameters and red bark are often found growing on karst. The trees are thought to have aged, however, environmental factors become a limiting factor for growth and cause a small trunk diameter. Conversely, S. quadrifida trees found on thick soil solum land or near waterways are more than $30 \mathrm{~cm}$ in diameter and are generally brighter (yellowish) in bark colour.

\section{Extraction yield and flavonoid content}

Based on growth altitude and diameter classes, 105 samples of $S$. quadrifida bark were grouped into 36 sample group. The sample trees were found at altitudes of $0-1,002 \mathrm{~m}$ a.s.l, from the coastline in Kupang city to Bu'at village in Timor Tengah Selatan District. The S. quadrifida trees are mostly found at elevations $<400 \mathrm{~m}$ a.s.l and are not found at altitudes of 1,100-1,500 $\mathrm{m}$ a.s.l (e.g. in Mount Mutis).

The highest extraction yield was obtained from the diameter class of $15-30 \mathrm{~cm}(4.75 \% \pm$ 1.23), and the least was obtained from the largest diameter class $>30 \mathrm{~cm}(3.59 \% \pm 0.66)$. The highest extraction yield was obtained from nonstripped bark samples at an altitude of $\leq 300 \mathrm{~m}$ a.s.l in all diameter classes (Table 1). The growth altitude significantly affected the extraction yield from $S$. quadrifida bark, whereas the diameter class did not (Table 2). The extraction yield was reduced and the colour was faded in each

Table 1 Colour classification and flavonoid content of Sterculia quadrifida bark colour and its flavonoid content

\begin{tabular}{|c|c|c|c|c|c|c|}
\hline No. & $\begin{array}{l}\text { Colour } \\
\text { group }\end{array}$ & $\begin{array}{c}\text { Munsell } \\
\text { colour code }\end{array}$ & Notation & $\begin{array}{c}\text { Mean extract } \\
\pm \mathrm{SD}(\%)\end{array}$ & $\begin{array}{l}\text { Mean flavonoid } \\
\quad \pm \text { SD }(\%)\end{array}$ & $\begin{array}{c}\text { Mean flavonoid } \\
\text { of colour group } \\
(\%)\end{array}$ \\
\hline 1 & \multirow[t]{6}{*}{ Red } & 2,5 yr $4 / 6$ & Red & $4.74 \pm 0.7$ & $0.21 \pm 0.03$ & \multirow[t]{6}{*}{0.25} \\
\hline 2 & & 2,5 yr $4 / 8$ & Red & $4.46 \pm 0.76$ & $0.39 \pm 0.07$ & \\
\hline 3 & & 2,5 yr $5 / 8$ & Red & $4.16 \pm 0.24$ & $0.17 \pm 0.05$ & \\
\hline 4 & & 5 yr $4 / 6$ & Yellowish red & $4.06 \pm 0.12$ & $0.15 \pm 0.04$ & \\
\hline 5 & & 5 yr $5 / 6$ & Yellowish red & $2.81 \pm 1.04$ & $0.25 \pm 0.06$ & \\
\hline 6 & & 5 yr $5 / 8$ & Yellowish red & $8.9 \pm 0.2$ & $0.20 \pm 0.06$ & \\
\hline 7 & \multirow[t]{7}{*}{ Brown } & 5 yr $4 / 4$ & Reddish brown & $5.16 \pm 1.6$ & $0.10 \pm 0.02$ & \multirow[t]{7}{*}{0.17} \\
\hline 8 & & 7.5 yr $4 / 4$ & Brown & $8.33 \pm 0.4$ & $0.26 \pm 0.05$ & \\
\hline 9 & & 7.5 yr $4 / 6$ & Strong brown & $1.9 \pm 0.14$ & $0.19 \pm 0.04$ & \\
\hline 10 & & 7.5 yr $5 / 8$ & Strong brown & $3.47 \pm 0.2$ & $0.13 \pm 0.03$ & \\
\hline 11 & & $10 \mathrm{yr} 4 / 4$ & Dark yellowish brown & $4.0 \pm 1.13$ & $0.09 \pm 0.04$ & \\
\hline 12 & & 10 yr $5 / 6$ & Yellowish brown & $2.53 \pm 0.31$ & $0.15 \pm 0.06$ & \\
\hline 13 & & 10 yr $5 / 8$ & Yellowish brown & $2.21 \pm 0.73$ & $0.13 \pm 0.03$ & \\
\hline
\end{tabular}


Table 2 Percentage yields of Sterculia quadrifida bark extraction

\begin{tabular}{lcccccc}
\hline $\begin{array}{l}\text { Diameter } \\
\text { classes }(\mathrm{cm})\end{array}$ & $\mathbf{N}$ & $\leq 300$ & $>300-600$ & $>600-900$ & $>900$ & \multirow{2}{c}{$\begin{array}{c}\text { Mean }(\%) \\
\pm \mathrm{SD}\end{array}$} \\
\cline { 3 - 6 } & 12 & 6.80 & 3.19 & 3.20 & 3.81 & $4.25 \mathrm{a} \pm 1.73$ \\
$>15$ & 12 & 6.59 & 4.04 & 4.29 & 4.09 & $4.75 \mathrm{ba} \pm 1.23$ \\
$>30$ & 12 & 5.89 & 3.05 & 1.97 & 3.47 & $3.59 \mathrm{ca} \pm 0.66$ \\
\hline Mean $\pm \mathrm{SD}$ & 36 & $6.43 \mathrm{a} \pm 0.48$ & $3.43 \mathrm{~b} \pm 0.54$ & $3.15 \mathrm{~b} \pm 1.16$ & $3.79 \mathrm{~b} \pm 0.31$ & $4.20 \pm 1.51$ \\
\hline
\end{tabular}

Similar letters within a column indicate the absence of a significant difference (Siswadi 2015)

re-maceration. The extract's colour was reddishbrown, which is associated with tannin content (Raju et al. 2008).

The $S$. quadrifida bark extraction yield had a very weak correlation $(r=0.217, p>0.05)$ with total flavonoid content. The findings were consistent with a study reported by Maulana et al. (2019), who concluded that the extraction yield was not correlated to flavonoid content. Therefore, it can be inferred that the obtained extract yield cannot indicate the flavonoid content. Another study finds a negative correlation between extraction yield and total flavonoid (Braga et al. 2016).

The highest level of flavonoids was obtained from an altitude of $\leq 300 \mathrm{~m}$ a.s.l $(0.21 \%)$ and the lowest was from $>600-900 \mathrm{~m}$ a.s.1 $(0.12 \%)$. Based on Table 3, total flavonoid content in diameter class $>15-30 \mathrm{~cm}$ was the highest $(0.22 \%)$, followed by diameter class $>30 \mathrm{~cm}$ $(0.16 \%)$, and $\leq 15 \mathrm{~cm}(0.12 \%)$. Flavonoids are part of phenolic compounds contained in the extract, at an average of $0.16 \%$. The flavonoid content of $S$. quadrifida bark is smaller than Acacia ataxacantha bark $(0.24 \%)$ but a lot more than Sterculia foetida $(0.07 \%)$ and Pterygota alata $(0.03 \%)$ (Amoussa et al. 2015, Siswadi \& Saragih 2017). Growth altitude significantly influenced the total flavonoids produced (Table 4). Research on Iresine herbstii also finds a correlation between elevation and flavonoid content (Safrina 2018). However, flavonoid content is not influenced by season, as reported by Lim et al. (2017).

Meanwhile, the diameter class also significantly affected the total flavonoids

Table 3 Anova of growth altitudes and diameter classes on extract yield of Sterculia quadrifida bark

\begin{tabular}{lcccccc}
\hline SV & SS & Df & MS & F hit & F tab (0.05) & Significance \\
\hline Altitude & 61.548 & 3 & 20.516 & 12.056 & 3.009 & 0.000 \\
Diameter & 8.098 & 2 & 4.049 & 2.337 & 3.403 & 0.114 \\
Altitude*diameter & 3.671 & 6 & 0.612 & 0.359 & 2.508 & 0.897 \\
Error & 40.876 & 24 & 1.703 & & & \\
Total & 114.194 & 35 & & & & \\
\hline
\end{tabular}

$\mathrm{SV}=$ source of variation, $\mathrm{SS}=$ sum of squares, $\mathrm{Df}=$ degree of freedom, $\mathrm{MS}=$ mean squares, $\mathrm{F}=\mathrm{F}$ ratio, $\mathrm{R}^{2}=0.642$, adjusted $\mathrm{R}^{2}=0.48$

Table 4 Total flavonoid content of Sterculia quadrifida bark

\begin{tabular}{|c|c|c|c|c|c|c|}
\hline \multirow{2}{*}{$\begin{array}{c}\text { Diameter } \\
\text { classes }(\mathrm{cm})\end{array}$} & & \multicolumn{4}{|c|}{ Growth altitude (m a.s.l) } & \multirow{2}{*}{$\begin{array}{c}\text { Mean (\%) } \\
\pm \mathrm{SD}\end{array}$} \\
\hline & & $\leq 300$ & $>300-600$ & $>600-900$ & $>900$ & \\
\hline$\leq 15$ & 12 & 0.16 & 0.10 & 0.09 & 0.12 & $0.12 \mathrm{a} \pm 0.03$ \\
\hline$>15-30$ & 12 & 0.32 & 0.20 & 0.16 & 0.18 & $0.22 b \pm 0.06$ \\
\hline$>30$ & 12 & 0.16 & 0.22 & 0.11 & 0.12 & $0.16 a \pm 0.04$ \\
\hline Mean $\pm \mathrm{SD}$ & 36 & $0.21 \mathrm{a} \pm 0.06$ & $0.17 \mathrm{ab} \pm 0.03$ & $0.12 b \pm 0.04$ & $0.14 b \pm 0.06$ & $0.16 \pm 0.05$ \\
\hline
\end{tabular}

*Similar letters within a column indicates the absence of significant difference (Siswadi 2015) 
produced by $S$. quadrifida tree. Some studies conclude that there is a correlation between diameter class and phytochemical content of the bark. In a study of tannin content in the bark of Terminalia cuneata, it was found that tannin in the bark of a tree with a diameter of $25-30 \mathrm{~cm}$ is a lot more than that of 30-35 cm (Mokat et al. 2013). Pandey \& Kori (2009) states that more tannin concentrations are found in trees with a circumference of about $41 \mathrm{~cm}$ compared with trees with a circumference of more than $63 \mathrm{~cm}$. Besides, it is also reported that bark that has never been peeled contains more tannins than regenerated ones (Pandey \& Mandal 2012).

However, interaction between growth altitude and diameter class did not occur. The significant value of each variable was obtained by adjusted $\mathrm{R}^{2}$ of 0.48 (Table 5), which means this model could explain the trend that occurred by $48 \%$. Thus, the altitude factor did not interact directly with the tree diameter class in producing total flavonoid content differences.

Information on soil and climatic parameters at each sampling location is presented in Table
6. The S. quadrifid tree's habitat at altitude $\leq 300 \mathrm{~m}$ a.s.l has thin soil solum, while at a higher altitude, the soil was thicker. The lower the elevation, the more area is dominated by karst. Timor Island is dominated by a stretch of karst, which is characterised by excessive infiltration rate and thin soil solum (Liu et al. 2020). Soil texture at each altitude was different. The soil $\mathrm{pH}$ was generally neutral in all sites. The CEC and C-organic in all locations were high, so that the differentiating factors of extract yield and flavonoid levels were presumably not derived from these parameters.

Unlike soil parameters, which were almost the same in all locations, the four altitude strata climatic conditions were different. The S. quadrifida that grew at altitude $\leq 300 \mathrm{~m}$ a.s.l was in fairly open land, thus, the intensity of sunlight received was relatively high. At an altitude of $>300 \mathrm{~m}$ a.s.l, S. quadrifida trees grew under shade. It is suggested by another study that plant parts under shade have lower flavonoid compared to sunlight exposed parts (Wang et al. 2005).

Table 5 Anova of growth altitudes and diameter classes on total flavonoid content of Sterculia quadrifida bark

\begin{tabular}{lcccccc}
\hline SV & SS & Df & MS & F hit & F tab (0.05) & Significance \\
\hline Altitude & 0.043 & 3 & 0.014 & 4.159 & 3.009 & 0.017 \\
Diameter & 0.062 & 2 & 0.031 & 9.016 & 3.403 & 0.001 \\
Altitude*diameter & 0.031 & 6 & 0.005 & 1.506 & 2.508 & 0.219 \\
Error & 0.082 & 24 & 0.003 & & & \\
Total & 0.217 & 35 & & & & \\
\hline
\end{tabular}

$\mathrm{SV}=$ source of variation, $\mathrm{SS}=$ sum of squares, $\mathrm{Df}=$ degree of freedom, $\mathrm{MS}=$ mean squares, $\mathrm{F}=\mathrm{F}$ ratio, $\mathrm{R}^{2}=0.622$, adjusted $\mathrm{R}^{2}=0.45$

Table 6 Sterculia quadrifida sites' soil and climatic characteristics

\begin{tabular}{ccccccccc}
\hline & \multicolumn{4}{c}{ Soil parameters } & \multicolumn{3}{c}{ Climatic parameters } \\
\cline { 2 - 9 } $\begin{array}{c}\text { Altitude } \\
(\mathrm{m} \text { a.s.l })\end{array}$ & $\begin{array}{c}\text { Soil texture } \\
\text { class }\end{array}$ & $\begin{array}{c}\text { CEC } \\
(\mathrm{me} / 100 \mathrm{~g})\end{array}$ & $\begin{array}{c}\text { C-organic } \\
(\%)\end{array}$ & $\begin{array}{c}\mathrm{pH} \\
\left(\mathrm{H}_{2} \mathrm{O}\right)\end{array}$ & $\begin{array}{c}\text { *Rainfall } \\
(\mathrm{mm})\end{array}$ & $\begin{array}{c}\text { Relative } \\
\text { humidity } \\
(\%)\end{array}$ & $\begin{array}{c}\text { Average } \\
\text { temperature } \\
\left({ }^{\circ} \mathrm{C}\right)\end{array}$ & $\begin{array}{c}\text { Relative } \\
\text { light } \\
\text { intensity } \\
(\%)\end{array}$ \\
\hline$\leq 300$ & $\begin{array}{c}\text { Sandy clay } \\
\text { loam }\end{array}$ & 37.13 & 5.48 & 6.65 & 1452.99 & 72.15 & 26.44 & 95.02 \\
$>300-600$ & Sandy loam & 24.71 & 3.99 & 7.84 & 1443.52 & 82.48 & 26.23 & 54.17 \\
$>600-900$ & Loam & 35.17 & 4.40 & 7.77 & 1557.18 & 84.03 & 23.00 & 56.06 \\
$>900$ & Loam & 29.62 & 3.15 & 7.68 & 1581.46 & 75.48 & 21.75 & 76.32 \\
\hline
\end{tabular}

*Average total rainfall, 2010-2014 [Pusat Sains dan Teknologi Atmosfer, LAPAN, 2020, NCEP-NCAR Reanalysis 1, National Oceanic and Atmospheric Administration (NOAA) ] 
Air temperature and humidity at altitude $\leq 300 \mathrm{~m}$ a.s.l were the highest compared to other locations. The climatic condition at this altitude is thought to cause high-temperature stress on S. quadrifida trees. Presumed, high flavonoid content at elevations of less than or equal to $300 \mathrm{~m}$ a.s.l is mainly due to temperature stress, which is in line with previous studies. Flavonoids are produced by plants as a form of plant protection from UV rays, drought and heat, and then accumulate in stems and leaves (Mierziak et al. 2014, Khalid et al. 2019). A study done by Li et al. (2018) reveals that sunlight intensity is the main factor for flavonoid content in the fruits of Rosa sterilis. It was likely that environmental factors such as UV radiation and temperature have more effects on flavonoid content (Wang et al. 2005).

\section{CONCLUSIONS}

Sterculia quadrifida bark colour could not be used as an indicator to estimate flavonoid content levels. However, this study indicated that red and yellow bark had a higher flavonoid content compared to brown and orange bark. The highest total extract and flavonoid yields was produced from altitude class $\leq 300 \mathrm{~m}$ a.s.l, and from diameter classes $>15-30 \mathrm{~cm}$. Therefore, in order to get higher extract and flavonoid yields, S. quadrifida bark should be chosen from trees with a diameter of $>15-30 \mathrm{~cm}$, growing at altitude $\leq 300 \mathrm{~m}$ a.s.l.

\section{ACKNOWLEDGEMENTS}

Acknowledgment is given to the Kupang Environment and Forestry Research Institute for providing research funding. The authors also thank Lalus M, Kristo, Misa C, Banani F and Betty $\mathrm{J}$ for their assistance in sample collection. This paper is part of the author's thesis supervised by Faridah E and Hertiani T.

\section{REFERENCES}

Akter K, Barnes EC, Brophy JJ ET AL. 2016. Phytochemical profile and antibacterial and antioxidant activities of medicinal plants used by aboriginal people of New South Wales, Australia. Evidence-Based Complementary and Alternative Medicine 2016: 1-14. doi.org/10.1155/2016/4683059.

Amoussa AMO, SANNI A \& LAgniKa L. 2015. Antioxidant activity and total phenolic, flavonoid and flavonol contents of the bark extracts of Acacia ataxacantha. Journal of Pharmacognosy and Phytochemistry 4: 172-178.

Balai Penelitian Tanah. 2004. Petunjuk Teknis Pengamatan Tanah. Pusat Penelitian dan Pengembangan Tanah dan Agroklimat. Badan Penelitian dan Pengembangan Pertanian, Departemen Pertanian, Bogor.

Balai Penelitian Tanah. 2009. Analisis Kimia Tanah, Tanaman, Air dan Pupuk Petunjuk Teknis Edisi 2. Balai Penelitian Tanah, Bogor.

Braga GC, Melo PS, Bergamaschi KB, Tiveron AP, Massarioli AP \& De Alencar SM. 2016. Extraction yield, antioxidant activity and phenolics from grape, mango and peanut agro-industrial by-products. Ciência Rural 46: 1498-1504. doi.org/10.1590/0103$8478 \mathrm{cr} 20150531$.

Chang CC, Yang MH, Wen HM \& Chern JC. 2002. Estimation of total flavonoid content in propolis by two complementary colourimetric methods. Journal of Food and Drug Analysis 10: 178-182. doi. org/10.38212/2224-6614.2748.

DeveoĞLu O \& Karadă̆ R. 2019. A Review on the flavonoids - A dye source. International Journal of Advances in Engineering and Pure Sciences 31: 188-200. doi.org/ $10.7240 /$ jeps. 476514 .

Gupta VK. 2019. Fundamentals of Natural Dyes and Its Application on Textile Substrates. Chemistry and Technology of Natural and Synthetic Dyes and Pigments. IntechOpen, London.

Harborne JB. 1988. The Flavonoids, Advances in Research Since 1980. Springer Science \& Business Media, Dordrecht.

Hertiani T, Purwantiningsih, Winanta A, Sasikirana W, Munawaroh R, Setyowati EP, Murwanti R \& Siswadi. 2019. In vitro immunomodulatory and cytotoxic potentials of faloak (Sterculia quadrifida R.Br.) bark. OnLine Journal of Biological Sciences 19: 222-231. doi. org/10.3844/ojbsci.2019.222.231.

Karthikeyan S, Shanthi P, Saravanan A \& Saranya K. 2014. Sorption of basic dye (Rhodamine B) by nano porous activated carbon from Sterculia quadrifida shell waste. Journal of Environmental Nanotechnology 3: 88-100. doi. org/10.13074/jent.2013.12.132087.

Kementrian Kesehatan Republik Indonesia. 2011. Suplemen IIFarmakope Herbal Indonesia Edisi I. Jakarta Direktorat Jenderal Bina Kefarmasian dan Alat Kesehatan, Jakarta.

Khalid M, BiLAL M \& Huang DF. 2019. Role of flavonoids in plant interactions with the environment and against human pathogens - A review. Journal of Integrative Agriculture 18: 211-230. doi.org/10.1016/S20953119(19)62555-4.

Lim TY, Lim YY \& Yule CM. 2017. Distribution and characterisation of phenolic compounds in Macaranga pruinosa and associated soils in a tropical peat swamp forest. Journal of Tropical Forest Science 29: 509-518. doi.org/10.26525/jtfs2017.29.4.509518.

Li J, Quan W, Li C, Shi D, Hu J, Jin J \& Ruan WQ. 2018. Effects of ecological factors on content of flavonoids in Rosa sterils from different karst areas of Guizho, SW China. Pakistan Journal of Botany 50: 1125-33.

Liu Y, Liu C, Rubinato M, Guo K, Zhou J \& Cui M. 2020. An assessment of soil's nutrient deficiencies and their influence on the restoration of degraded karst 
vegetation in Southwest China. Forests 11: 797-802. doi.org/10.3390/f11080797.

Lulan TYK, Fatmanati S, Santoso M \& Ersam T. 2018. Antioxidant capacity of some selected medicinal plants in East Nusa Tenggara, Indonesia: The potential of Sterculia quadrifida $\mathrm{R}$. Br. Free Radicals and Antioxidants 8: 96-101. doi.org/10.5530/ fra.2018.1.15.

Malviya N \& Mahajan S. 2013. Preliminary phytochemical screening of bark of some important trees of college campus with special reference to tannin, glycoside and their medicinal properties. International Research Journal of Environmental Sciences 2: 13-17.

Manik DF, Hertiani T \& Anshory H. 2014. Analisis korelasi antara kadar flavonoid dengan aktivitas antibakteri ekstrak etanol dan fraksi-fraksi daun kersen (Muntingia calabura L.) terhadap Staphylococcus aureus. Khazanah: Jurnal Mahasiswa UII 6: 1-12.

MaU R. 2010. Ecosystem and community based model for Zonation in Nino Konis Santana National Park, Timor-Leste. MSc thesis. Institut Pertanian Bogor, Bogor.

Maulana TI, Falah S \& Andrianto D. 2019. Total phenolic content, total flavonoid content, and antioxidant activity of water and ethanol extract from Surian (Toona sinensis) leaves. IOP Conference Series, Earth and Environmental Science. The $5^{\text {th }}$ International Seminar on Sciences. $25^{\text {th }}$ October 2018, Bogor, Indonesia. doi.org/10.1088/1755-1315/299/1/012021.

Mhamdi B, Wannes WA, Sriti J, Jellali I, Ksouri R \& Marzouk B. 2010. Effect of harvesting time on phenolic compounds and antiradical scavenging activity of Borago officinalis seed extracts. Industrial Crops and Products 31: e1-e4. doi.org/10.1016/j. indcrop.2009.07.002.

Mierziak J, Kostyn K \& Kulma A. 2014. Flavonoids as important molecules of plant interactions with the environment. Molecules 19: 16240-16265. doi. org/10.3390/molecules191016240.

Mokat DN, Maku HC \& Narkhede SS. 2013. Effect of period of bark harvesting and diameter class on quality parameters of bark of Terminalia cuneata Roth. Ecology, Environment and Conservation Paper 19: 95-98.

Munsell Colour Company. 1994. Munsell Soil Colour Charts, Revised Edition. New Windsor, New York. https:// books.google.co.id/books?id=OosHfAEACAAJ.

PANDEY AK \& KorI DC. 2009. Variations in tannin and oxalic acid content in Terminalia arjuna (Arjuna) Bark. Pharmacognosy Magazine 5: 159-164.

PANDEY AK \& MANDAL AK. 2012. Sustainable harvesting of Terminalia arjuna (Roxb.) Wight \& Arnot (Arjuna) and Litsea glutinosa (Lour.) Robinson (Maida) bark in Central India. Journal of Sustainable Forestry 31: 294-309. doi.org/10.1080/10549811.2011.583865.

Peschel W, Prieto JM, Karkour C \& Williamson EM. 2013. Effect of provenance, plant part and processing on extract profiles from cultivated European Rhodiola rosea L. for medicinal use. Phytochemistry 86: 92-102. doi.org/10.1016/j.phytochem.2012.10.005.

Pusat Sains dan Teknologi Atmosfer LAPAN (National Institute of Aeronautics and Space). 2020. Data Parameter Iklim (Processed from NCEP-NCAR
Reanalysis 1). LAPAN Atmospheric Science Centre, West Java. https://psl.noaa.gov/data/gridded/data. ncep.reanalysis.html).

Raju AJS, Jonathan KH \& Rao SP. 2008. Traditional extraction of bark tannin from the mangrove tree, Ceriops decandra (Griff.) Ding Hou and its use in treating cotton fishing nets. Natural Product Radiance 7: 173-175.

Rollando R \& Prilianti KR. 2017. Fraksi etil asetat kulit batang faloak (Sterculia quadrifida R. Br) menginduksi apoptosis dan siklus sel pada sel kanker payudara T47D. Journal of Pharmaceutical Sciences and Community 14: 1-14. doi.org/10.24071/jpsc.141557.

Roshan-Jahn MS, Getha K, Mohd-Ilham A, Norhayati I, Muhammad-Haffiz J \& Amyra AS. 2018. In vitro antileismanial activity of Malaysian medicinal and forest plant species. Journal of Tropical Forest Science 30: 234-241. doi.org/10.26525/jtfs2018.30.2.234241.

SAFrina D. 2018. Pengaruh ketinggian tempat tumbuh dan pengeringan terhadap flavonoid total sambang colok (Iresine herbstii). Jurnal Penelitian Pascapanen Pertanian 15: 147-154. doi.org/10.21082/jpasca. v15n3.2018.147-154.

SARAgIH GS \& Siswadi S. 2019. Antioxidant activity of plant parts extracts from Sterculia quadrifida R. Br. Asian Journal of Pharmaceutical and Clinical Research 12: 143-148. doi.org/10.22159/ajpcr.2019.v12i7.33261.

Siswadi S, Saragih GS \& Rianawati H. 2013. Potential distributions and utilization of faloak (Sterculia quadrifida R. Br. 1844) on Timor Island, East Nusa Tenggara. Pp. 165-171 in Langi M et al. (eds.). Proceedings of International Conference on Forest and Biodiversity. 5- $6^{\mathrm{h}}$ July 2013, Manado, Indonesia.

Siswadi S, Rianawati H, Saragin GS \& Sulistyo DH. 2014. The potency of faloak's (Sterculia quadrifida R.Br.) active compunds as natural remedy. Pp 73-79 in Rizal M et al. (eds) Proceedings of International Seminar on Forests and Medicinal Plants for Better Human Welfare. 10-12 September 2013, Bogor, Indonesia.

Siswadi S. 2015. Rendemen ekstrak dan flavonoid total kulit batang pohon faloak (Sterculia quadrifida R.Br.) pada beberapa kelas diameter dan strata ketinggian tempat tumbuh. MSc thesis. Fakultas Kehutanan, Universitas Gadjah Mada, Yogyakarta.

Siswadi S \& SARAGIH GS. 2017. Kandungan flavonoid total kulit batang beberapa famili sterculiaceae; faloak (Sterculia quadrifida R.Br.) pterigota (Pterygota alata (Roxb.) R. Br.) dan nitas (Sterculia foetida L.). Pp 112-118 in Emrizal \& Fadhli (eds) Prosiding Seminar Nasional POKJANAS TOI ke-52. 12-13 April, 2017, Pekanbaru, Indonesia.

Siswadi S, Rianawati H, Umroni A, Hidayatullah M \& Saragih GS. 2020. Karakteristik pertumbuhan tanaman faloak (Sterculia quadrifida R.Br.) asal populasi Pulau Rote. Journal Penelitian Kehutanan FALOAK 4: 81-94. http://dx.doi.org/10.20886/jpkf.2020.4.2.81-94.

Vicente O \& Boscaiu M. 2018. Flavonoids: Antioxidant compounds for plant defence and for a healthy human diet. Notulae Botanicae Horti Agrobotanici ClujNapoca 46: 14-21. doi.org/10.15835/nbha46110992.

WANG W, Li X \& Zhang Y. 2005. Dynamic feature of flavonoids content in different organs of larch (Larix 
gmelinii). Journal of Forestry Research 16: 89-92. doi. org/10.1007/BF02857896.

Winanta A, Hertiani T, Purwantiningsih \& Siswadi. 2019. In vivo immunomodulatory activity of faloak bark extract (Sterculia quadrifida R.Br). Pakistan Journal of Biological Sciences 22: 590-596. doi.org/10.3923/ pjbs.2019.590.596.

Zvavamwe C, Mkandhla CK, Zvavamw C et al. 2016. Yellow dye extraction from Eucalyptus grandis bark. American Journal of Engineering Research 5: 10-18. 